CHAPTER 11

\title{
The Construction of Social Rights
}

Hartley Dean ${ }^{1}$

\section{Introduction}

It has been contended that the 'social dimension' of the EU is 'near collapse' and that we should take a 'sober view' of the potential of European Social Citizenship. ${ }^{2}$ The original concept of European Citizenship was primarily relevant for those citizens who wish and are able to move between Member States, while its influence upon the substantive rights of settled citizens has been relatively secondary or, at least, indirect. But if there is to be a meaningful social dimension to European citizenship it must be transparently effective not only for the lives intra-Union migrants, but also for the lives of that vast majority of EU citizens who do not move about, but 'stay at home'. ${ }^{3}$ Social rights are, and will continue primarily to be, legislated for and administered at national level. Over the years EU Directives have certainly had some practical consequences for domestic social protection policies across Europe, but EU influence over the rights of European citizens is, as Barbier puts it, to 'be indirectly observed, because of the growing power of EU economic law'. The concept of 'Social Europe' has been at best under-realised.

This chapter is concerned with the underlying social meaning of social rights. It draws upon the findings of a recent study ${ }^{6}$ that sought to investigate the ways in which social rights have been and are now socially and ideologically constructed across Europe. To frame the discussion, we shall first consider the relationship between social rights and citizenship, before outlining a summary account of the two principal components of that study. The first provides a revisionary historical analysis of the development of social rights in a selection of European countries. The second offers a tentative analysis of contemporary social rights discourse among key policy actors in those countries. In light of the study, the chapter finally turns to consider the barriers to consensus regarding the fundamental meaning of European social citizenship.

\section{Social rights and citizenship}

\footnotetext{
${ }^{1}$ The author is grateful to his colleague, Anne-Marie Brady, for invaluable research assistance; and to other members of the bEUcitizen Work Package 6 group for their substantive contributions.

${ }^{2}$ Barbier, Jean-Claude (2013), 'To What Extent Can the European Union Deliver 'Social Citizenship' to Its Citizens?', in ed. Adelbert Evers and Anne-Marie Guillemard (eds.), Social Policy and Citizenship: The Changing Landscape, Oxford: Oxford University Press, p. 105 and 108.

${ }^{3}$ A comment made by Phillipe van Parijs, speaking during an Open Forum Discussion at the bEUcitizen 'Kick Off' Conference, Utrecht, 18 September 2013.

${ }^{4}$ Barbier, Jean-Claude (2013), 'To What Extent Can the European Union Deliver 'Social Citizenship' to Its Citizens?', in ed. Adelbert Evers and Anne-Marie Guillemard (eds.), Social Policy and Citizenship: The Changing Landscape, Oxford: Oxford University Press, p. 100.

${ }^{5}$ Bailey, David (2008), 'Explaining the Underdevelopment of 'Social Europe': A Critical Realisation', Journal of European Social Policy 3 (18), 232-45.

${ }^{6}$ Dean, Hartley and Anne-Marie Brady (2015), The Social Construction of Social Rights across Europe (D6.3 Report). (Utrecht: bEUcitizen [Barriers towards EU citizenship] EU Seventh Framework Programme IP).
} 
It may be argued that social rights are best understood as 'articulations of human need'. They are constructed through the process by which human beings socially negotiate the naming and claiming of needs and the legitimacy of the demands that human beings place upon each other. The earliest human societies, as associations of interdependent beings, will have established customary rules for ensuring everyday wellbeing. In their struggle for survival and fulfilment, human beings have come in various ways to articulate the ethical premises by which to recognise the needs and claims of not only intimates and neighbours, but of distant strangers. ${ }^{8}$ In this sense, the construction of social rights preceded the emergence of cities or nation states and the development of formal law and political process. Social rights, as creatures of struggle and custom were, and are, fundamentally constitutive of our humanity. More recently and conventionally, however, social rights have been constitutionally constructed at two distinct levels: either concretely as components of welfare state citizenship ${ }^{9}$ or more abstractly as elements of the international human rights ${ }^{10}$ framework.

At the citizenship level, social rights are widely regarded as a 'Western' twentieth century invention, ushered in by advanced industrial capitalism and the creation of the modern welfare state. The ancient origins of citizenship as the exclusive status of a patrician male elite gave way, following the so-called European Enlightenment, to new modes of governance commensurate with the development of capitalism, ${ }^{11}$ and eventually to mechanisms by which, in highly complex affluent societies, it was potentially possible for the needs of all citizens to be met through mechanisms of collective distribution. ${ }^{12}$ Citizenship could be understood not only as a status, but as a practice: a practice with uneven and frequently suboptimal outcomes, not least because citizenship status evolved in ways that continued to marginalise, if not exclude, on the basis of class, gender, ethnicity and disability. ${ }^{13}$ But social rights had been evolving long before they were identified and named as social rights. And the social rights to which modern European welfare states supposedly gave birth had been preceded for centuries by a variety of customary, charitable and administrative practices, the nature of which inevitably influenced modern forms of social citizenship and shaped the emergence of social rights as creatures of policy and law: specifically rights to work, social security, health and social care, education and housing.

At the human rights level, a new generation of 'economic, social and cultural rights' (an expression for which the term 'social rights' is widely treated as a synonymous contraction) was formally announced by the UN's Universal Declaration of Human Rights of 1948 (the UDHR). The declaration gave expression, in the wake of two world wars, to a loose international consensus, ${ }^{14}$ driven in particular by a social liberal ideal summed up in a demand - variously espoused, for example, by Roosevelt ${ }^{15}$ and Beveridge ${ }^{16}$ - for individual

\footnotetext{
${ }^{7}$ Dean, Hartley (2013), 'The Translation of Needs into Rights: Reconceptualising Social Citizenship as a Global Phenomenon', International Journal of Social Welfare, 22 (1), S32-S49; Dean, Hartley (2015), Social Rights and Human Welfare, Abingdon: Routledge.

${ }^{8}$ Honneth, Axel (1995), The Struggle for Recognition: The Moral Grammar of Social Conflicts, Cambridge: Polity.

${ }^{9}$ Marshall, Thomas (1950), 'Citizenship and Social Class', in Thomas Marshall and Tom Bottomore (ed.), Citizenship and Social Class, London: Pluto, 1950.

${ }^{10}$ Donnelly, Jack (2013), Universal Human Rights in Theory and Practice, Ithaca (NY): Cornell University Press; Freeman, Michael (2011), Human Rights, Cambridge: Polity.

${ }^{11}$ Turner, Bryan (1986), Citizenship and Capitalism: The Debate over Reformism, London: Allen and Unwin.

${ }^{12}$ Titmuss, Richard (1970), The Gift Relationship, London: Allen and Unwin.

${ }^{13}$ Lister, Ruth (2003), Citizenship: Feminist Perspectives, Basingstoke: Macmillan.

${ }^{14}$ Davy, Ulrike (2013), 'Social Citizenship Going International: Changes in the Reading of Un-Sponsored Economic and Social Rights', International Journal of Social Welfare, 22 (1), S15-S31.

${ }^{15}$ Roosevelt, Franklin D. (1941), State of the Union Address to Congress.

${ }^{16}$ Beveridge, William (1942), Social Insurance and Allied Services, London: HMSO.
} 
freedom from 'Want'. The UN eventually in 1966 established separate International Covenants to give effect to the Universal Declaration: one for Civil and Political Rights, the other for Economic, Social and Cultural Rights. The latter allowed for the 'progressive realisation' of social rights as creatures of principle and doctrine, requiring state parties in the first instance to respect such rights; second to protect such rights; and third, so far as resources permitted, to fulfil such rights. In the meantime, the Council of Europe had in 1950 established the European Convention on Human Rights (the ECHR - primarily a civil and political rights treaty), and in 1961 the European Social Charter (the ESC - a social rights treaty). The ESC was revised and strengthened in 1996.

At the level of the European Union (EU) as a supra-national body, the pertinence of social rights has been somewhat ambiguous. The EU began life in 1957 primarily as an economic union (the European Economic Community), concerned fundamentally with market promotion rather than social protection. ${ }^{17}$ It has since been evolving as an incipient political union as much as an economic union, and in recent decades has to sought to extend cooperation between Member States into l'espace social, ${ }^{18}$ explicitly laying claim to a 'social dimension'. ${ }^{19}$ The EU promulgated a Charter of Fundamental Social Rights in 1989. Elements of this were incorporated as Social Protocols to the 1992 Maastricht Treaty (in which some reference to 'European Citizenship' first appeared), the 1997 Amsterdam Treaty, and finally into the Lisbon Treaty of 2009, which additionally included a 'horizontal social clause' that requires the EU, when defining and implementing its policies and activities, to 'take into account requirements linked to the promotion of a high level of employment, the guarantee of adequate social protection, the fight against social exclusion, and a high level of education, training and protection of human health' (Clause 9). Pessimists had previously contended that the EU social policy was no more than 'an empty shell' ${ }^{20}$ Optimists, however, suggest that the Lisbon Treaty potentially signified a mainstreaming of social policy issues. ${ }^{21}$ The EU Charter of Fundamental Social Rights incorporates elements of the ESC, but the rights it enshrines are arguably more symbolic than substantive.

\section{History}

History can tell us about the political and legal construction of social rights, but we are left to infer how social rights have been commonly regarded and understood; how the individual has been constituted in relation to her claims upon society; and how, by implication, the social subject may have been constituted in relation to the state. Politically and legally constituted social rights do not necessarily translate into de facto social rights, ${ }^{22}$ nor are they necessarily truly 'social' in the sense that they directly represent the substance and meaning of social relationships. ${ }^{23}$ The key to the social construction of social rights is the manner in which the

\footnotetext{
${ }^{17}$ Scharpf, Fritz (2002), 'The European Social Model: Coping with the Challenges of Diversity', Journal of Common Market Studies (4) 40: 645-70; Hantrais, Linda (2007), Social Policy in the European Union, Basingstoke: Macmillan.

${ }^{18}$ Delors, Jacques (1986), ‘ L'espace Social Européén', 2 EC 12.

${ }^{19}$ Commission for the European Communities (1993), European Social Policy: Options for the Union, Luxembourg: OOPEC.

${ }^{20}$ Falkner, Gerda (2000), 'The Treaty on European Union and Its Revision: Sea Change or Empty Shell for European Social Policies?', in Stein Kuhnle (ed.), Survival of the European Welfare State, London: Routledge.

${ }^{21}$ Vielle, Pascal (2010), 'How the Horizontal Social Clause Can Be Made to Work: The Lessons of Gender Mainstreaming', ETUI Policy Brief - European Social Policy, 6.

${ }^{22}$ Janoski, Thomas (1998), Citizenship and Civil Society: A Framework of Rights and Obligations in Liberal, Traditional and Social Democratic Regimes, Cambridge: Cambridge University Press.

${ }^{23}$ Isin, Engin et al. (2008), 'Recasting the Social in Citizenship' in Engin Isin (ed.), Recasting the Social in Citizenship, Toronto: University of Toronto Press.
} 
subjects or bearers of those rights are constituted. With this in mind, the author has attempted to synthesise an analysis of separate accounts, focused on the development of social rights in eight European countries. The accounts were specifically prepared for this purpose by scholars from each country. The countries included were as follows:

- Two, the Netherlands and Germany, were Western continental European countries and each had been founder Members of the European Economic Community in 1957. The Netherlands, has been characterised as a 'corporatist' or 'conservative/social democratic' hybrid welfare regime. Germany is characteristically regarded as a 'conservative' welfare regime.

- Two, Sweden and Denmark, were Nordic countries, generally classified as 'social democratic' welfare regimes.

- The UK, generally classified as a 'liberal' welfare regime. ${ }^{24}$

- Spain, is regarded as a distinctively 'Southern' or 'Mediterranean' welfare regime, ${ }^{25}$ though its foundations were strongly conservative/corporatist.

- Two, Poland and Estonia, were post-communist welfare regimes, albeit that the former is inclined to conservative traditions, and the latter to a liberal approach. ${ }^{26}$

Welfare regime classifications, while capturing patterns relating to factors such as decommodification and the extent of substantive social protection and provision, ${ }^{27}$ do not directly address themselves to social rights. Labour power and essential human services can be more or less highly commodified: that is to say, the sale of labour power and the provision of human services may to a greater or lesser extent be removed from the sphere of civil rights that governs the making of contracts and instead become subject to what may be characterised as social rights, but the significance in terms of 'rights' to protection and/or to access services will vary depending on just how the citizen or subject is conceptualised or constituted and it was to this that the analysis addressed itself. The focus was on a timeframe from the latter part of the nineteenth century to the early part of the twenty-first century. This is the period in which modern welfare states developed. It was a period punctuated by two world wars; by the rise and fall of communism; and by global financial crises. The aim was to interpret the narrative accounts provided in relation to historical phases, social policy developments and constitutional milestones. A detailed account of the analysis is provided elsewhere ${ }^{28}$ but it identified the following four intersecting influences on the social construction of the rights-bearing subject across Europe:

\subsection{Religion and the framing of the Poor Laws}

In all eight countries, the emergence of the welfare state was preceded by charitable poor relief, administered initially at parish level by the Church. Such administration was subject by stages to varying degrees of legal regulation through the Poor Laws. Whereas it was

\footnotetext{
${ }^{24}$ The work was conducted prior to the 2016 referendum by which the UK voted to leave the EU.

${ }^{25}$ Ferrera, Maurizio (2005), The Boundaries of Welfare: European Integration and the New Social Politics of Social Protection, Oxford: Oxford University Press; Bonoli, Guiliana (1997), 'Classifying Welfare States', Journal of European Social Policy (2) 26, 352-72.

${ }^{26}$ Cerami, Alfio and Pieter Vanhuysse (2009), Post-Communist Welfare Pathways: Theorizing Social Policy Transformations in Central and Eastern Europe, Basingstoke: Palgrave.

${ }^{27}$ Esping-Andersen, Gøsta (1990), The Three Worlds of Welfare Capitalism, Cambridge: Polity; Ferragina, Emanuelle and Martin Seeleib-Kaiser (2011), 'Thematic Review: Welfare Regime Debate - Past, Present, Futures?', Policy and Politics 4 (39), 583-611.

${ }^{28}$ Dean, H. and A. Brady (2015), The Social Construction of Social Rights across Europe (D6.3 Report).
} 
originally largely Catholic doctrine that governed the more or less arbitrary collection and distribution of alms, following the Reformation, ever closer attention was paid to systematic provision and to the distinction between supposedly deserving and undeserving supplicants. Famously, Martin Luther urged the prohibition of begging and the reform of relief systems (Liber Vagatorum, 1528), and from the sixteenth century onwards the trend towards stigmatising conditionality in the administration of poor relief could subsequently be observed across Europe in Catholic and Protestant countries alike. ${ }^{29}$ Nevertheless, the tension between the underlying logic of Catholic and Protestant traditions continued to have some influence on the emphasis and design of secular Poor Laws until the nineteenth century. As we have noted, Catholic social doctrine would evolve in ways that would accommodate the coming of the modern welfare state, but its initial impetus favoured conservative principles of charity and noblesse oblige, casting the individual as a supplicant, subject to the traditions of the social order and the authority of the Church; in contrast to the idea of the individual as a different kind of supplicant, accountable ultimately, it was supposed, to God, but who's maintenance and conduct might nevertheless be subject to state regulation. ${ }^{30}$

\subsection{Capitalism and the 'social question'}

It may be seen that across Europe before, or soon after, the turn of the twentieth century there was what might be regarded as a strategic social liberal 'turn'; a wave of concern amongst liberal/bourgeois intellectuals about the social consequences and diswelfares of industrial capitalist development. It was a concern motivated as much by self-interest as compassion, but an impetus to what might be aptly described as a form of 'reluctant collectivism'. ${ }^{31}$ Social liberal thinking may be seen to have played a decisive part in the creation before WWII of incipient welfare states in all of the eight countries we have studied. In some instances these early developments were interrupted, but in every instance they seem to have provided the foundations on which forms of provision for social rights would eventually be founded. What these developments had in common was that they each re-constituted those who might have been potential supplicants under the Poor Laws as workers within the capitalist economy. Social liberalism was not the only ideological influence: social conservative and social democratic influences were also at work. But the organising principle around which social liberalism achieved a strategic consensus was that of social insurance. The social insurance principle appeals uniquely both to individualistic and solidaristic ideals. It entails individual contribution and collective risk sharing. It is authoritarian insofar as membership and contributions are compulsory and insurance schemes are rule-bound. But it is also emancipating, since it creates indisputable rights for workers to benefits, pensions and/or health treatment. It provided a common foundation for modern welfare states.

\subsection{Constitutional citizenship}

There is no straightforward connection between the extent to which, or the manner in which, provision for social rights that are explicitly written into national constitutions is reflected in countries' commitment either to supranational social rights treaties (such as the revised ESC or EU Social Protocols), or to the precise configuration of national welfare states.

Nevertheless, it is through constitutions that rights of citizenship are explicitly or implicitly defined. In four of the eight countries studied (Germany, Spain, Poland and Estonia),

\footnotetext{
${ }^{29}$ Foucault, Michel (1965), Madness and Civilisation: A history of insanity in the Age of Reason, London: Tavistock.

${ }^{30}$ Dean, Hartley (1991), Social Security and Social Control, London: Routledge.

${ }^{31}$ George, Vic and Paul Wilding (1985), Ideology and Social Welfare, London: Routledge and Kegan Paul.
} 
constitutions with express provision for social rights were adopted, albeit fleetingly, in the period between WWI and WWII; in three (Sweden, Denmark and the Netherlands), a clear constitutional commitment appeared only after a welfare state was fully established; and the UK has never had a written constitution. The earlier constitutions were all quite similar and bore the imprint of the social liberal wave alluded to above. The later constitutions reflected the language of the UDHR and/or the ECHR/ESC. The common feature of the thinking that contributed to all these documents, and by which the citizen as a bearer of rights was therefore constructed, was an element of liberal individualism. The subject of social rights was, in theory and in part, not only a worker (or, less directly, the dependant of a worker) but an individual citizen. ${ }^{32}$

\subsection{Changing economic orthodoxies}

The 'Golden Age' 33 of post-WWII social citizenship accommodated a form of social liberal/social conservative/social democratic consensus, a phenomenon in which six of the eight countries we have studied were able to participate, while two (Poland and Estonia) were at that time subject to state communist control, albeit that this did entail state provision for the social protection of workers. The crisis that befell the capitalist welfare states in the 1970s precipitated changes that have been variously interpreted as retrenchment, residualisation or recalibration; and the subsequent era has been variously described as post-industrial, postFordist or post-modern. ${ }^{34}$ Welfare states remained relatively resilient but have responded - to a greater or lesser extent - to changes in prevailing economic orthodoxy; a neoliberal orthodoxy whose influence extends to the economic priorities adopted by the $\mathrm{EU}^{35}$ and, of course, to the post-communist countries that have re-entered the capitalist welfare state fold since 1990. None of the capitalist welfare states studied have been wholly immune from the trend from Keynesian Welfare State to what Jessop has characterised as the Schumpeterian Workfare or Competition State, ${ }^{36}$ and in particular, the trend to liberalisation or recommodification of public utilities that the EU actively promotes. ${ }^{37}$ As a result the subject of social rights may now be socially reconstituted, not as a citizen, but in part as a consumer of public services, such as healthcare and educational provision; ${ }^{38}$ or once again in the case of workers subject to 'workfare'-style labour market activation policies, as a supplicant ${ }^{39}$

What this review of country case histories tended to confirm was that underlying the very different trajectories of these eight European countries were certain key transitions in common. The end of the Poor Laws across Europe at, or around, the turn of the twentieth century was driven by a social liberal turn, by which certain subjects of social rights who had been socially constituted as supplicants were reconstituted as workers facing potentially insurable risks. Over time and at different stages welfare state regimes emerged which

\footnotetext{
${ }^{32}$ While the original highly gendered nature of social insurance-based welfare regimes systemically benefited the male bead-winner citizen and subordinated the social rights of women, the emergence of independent rights of women has since the 1970s been advanced to some extent through EU equal treatment directives.

${ }^{33}$ Esping-Andersen, Gøsta (1999), The Social Foundations of Post-Industrial Economies, Oxford: Oxford University Press.

${ }^{34}$ Powell, Martin and Martin Hewitt (2002), Welfare State and Welfare Change, Buckingham: Open University Press.

${ }^{35}$ Hermann, Christoph (2007), 'Neoliberalism in the EU', Studies in Political Economy 79, 61-89.

${ }^{36}$ Jessop, Bob (2002), The Future of the Capitalist State, Cambridge: Polity.

${ }^{37}$ Leibried, Stephan (2000), 'National Welfare States, European Integration and Globalization: A Perspective for the Next Century', Social Policy and Administration 1 (34), 44-63.

${ }^{38}$ Newman, Janet ed. (2005), Remaking Governance: Peoples, Politics and the Public Sphere, Bristol: The Policy Press.

${ }^{39}$ Brodkin, Evelyn and Gregory Marston eds. (2013), Work and the Welfare State, Copenhagen: DJØF Publishing.
} 
socially constituted the subjects of social rights - sometimes ambiguously - as citizens of equal social status. But since the 1970s, subject to the influence of neoliberal economic and managerial orthodoxies, as bearers of social rights, some workers have again been constituted in part as supplicants and some citizens have been reconstituted as consumers. The social basis for social citizenship in Europe was never uniformly established and, arguably, is now unravelling.

\section{Discourses}

Reflecting afresh on the political and legal evolution of social rights reveals something about underlying social processes, but what is the legacy of such processes for the manner in which the current generation of European policy actors understand social rights? To investigate this question, a series of interviews were conducted in each of the eight countries identified above with key informants, including politicians, senior civil servants and professionals engaged in the framing, planning, delivery or oversight of social policies: actors with some degree of influence, representing dominant strands of opinion within, or close to, each country's policymaking establishment. In all, a diverse array of 55 such actors were interviewed. The purpose was to explore the discourse of these eight interconnected European social policy communities. Once again, a detailed account of the findings has been provided elsewhere. ${ }^{40}$ However, what the interviews revealed were inconsistent (and sometimes weak) conceptualisations of social rights; marked differences in the commitment or legitimacy attaching to different kinds of social rights (healthcare and education being more clearly regarded as rights than social assistance or housing); ambivalence as to whether responsibility for meeting need is, or can be, properly mediated by rights; and a certain tendency to largely technocratic categorisations of who is, or may be, the bearer of social rights.

More fundamentally, a detailed qualitative analysis of the interview transcripts revealed the extent to which respondents were drawing on a mixture of competing conceptual discourses. Several respondents made explicit references to the idea of a 'social contract'. But the apparent meaning attached to this idea varied between respondents and, on occasions, even within a respondent's own discourse. The various ways in which respondents framed their ideas of social rights, or the metaphorical 'contract' on which such rights are premised, exhibited some resonance with classic welfare regime models, but it is important to emphasise that respondents' discourses were not necessarily consistent with the welfare regimes of the countries from which they came. What could be detected, however, was an array of intersecting discourses encapsulating competing interpretations of a social contract. That array can be captured by way of a strictly heuristic taxonomy illustrated in Figure 8.1. The taxonomy has resonance with the author's past attempt to model the discursive moral repertoires relating to social citizenship to be found in popular discourse. ${ }^{41}$ Here it may be regarded as a methodological device by which to explore the quotidian understandings resorted to by the policy actors interviewed for the current study: understandings by which they made sense of the often 'ungraspable' complexity of the policy environment in which they functioned ${ }^{42}$ and which characterise the 'clumsy solutions' that may be brought to bear even by the most sophisticated policy actors - in a complex world. ${ }^{43}$

\footnotetext{
${ }^{40}$ Dean, H. and A. Brady (2015), The Social Construction of Social Rights across Europe (D6.3 Report).

${ }^{41}$ Dean, Hartley and Margaret Melrose (1999), Poverty, Riches and Social Citizenship, Basingstoke: Macmillan.

${ }^{42}$ Sum, Ngai-Ling and B. Jessop (2013), Towards Cultural Political Economy: Putting Culture in Its Place in Political Economy, Cheltenham: Edward Elgar.

${ }^{43}$ Verweij, Marco and Michael Thompson eds. (2006), Clumsy Solutions for a Complex World: Governance, Politics and Plural Perceptions, Basingstoke: Palgrave Macmillan.
} 


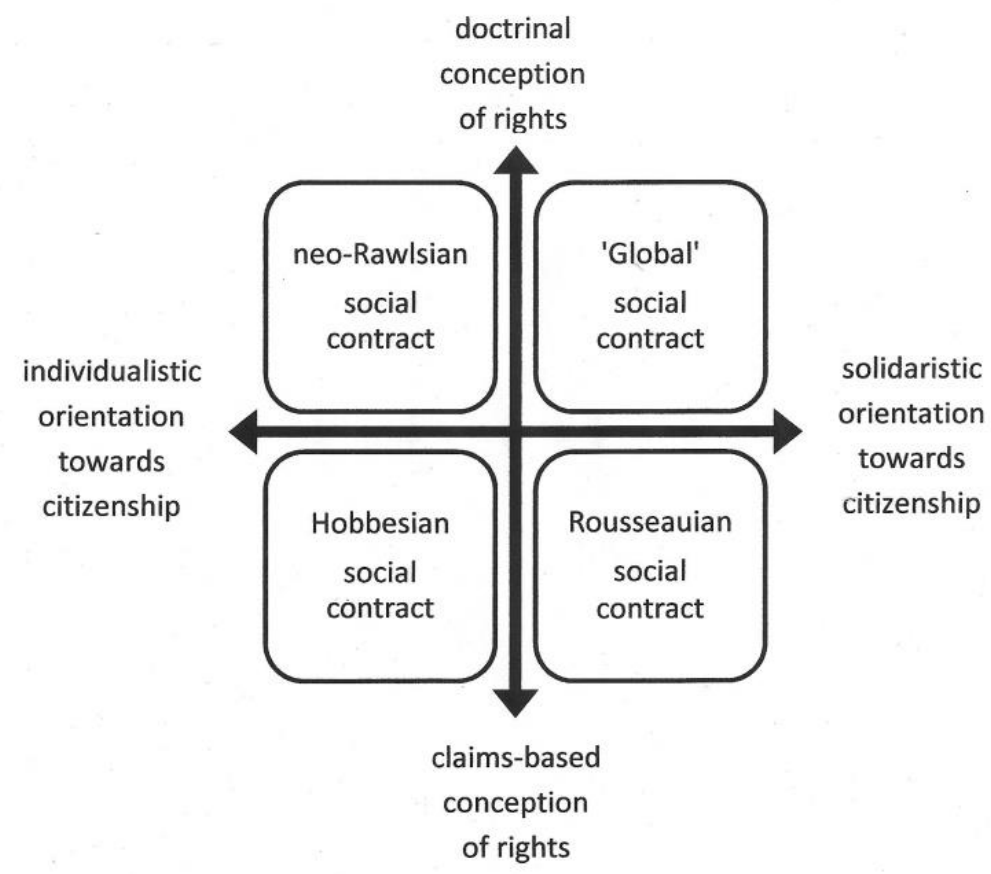

Figure 8.1: Social contract discourse: a taxonomy

The taxonomy presented is constructed around two axes: one distinguishes between individualistic and solidaristic orientations to the nature of the contract between the individual and society; the other distinguishes between, on the one hand, doctrinal conceptions of rights (as rights inherent to personhood) and, on the other, claims-based conceptions of rights (as rights that are pragmatically framed and/or contextually grounded). The distinctions represented by each axis are dynamic rather than simple binary distinctions: the axes are conceptual devices for understanding dialectical processes. Humans negotiate life both as individual and as social beings. Rights are realised through an interaction between 'top-down' doctrines and 'bottom-up' claims. The labels chosen to characterise the different social rights discourses are intended primarily as convenient short-hand identifiers and do not imply anything beyond relatively superficial - some will say tenuous philosophical connections.

- A social contract based on a doctrinal conception of rights and a solidaristic orientation would espouse an essentially universalistic ethos and cosmopolitan/human rights principles. We might label this 'global': that is to say it holds that rights are founded in ethical principles and an ideal of shared humanity. 'Global' might here refer literally to internationally defined human rights, or metaphorically to shared rights of a community or a people. This approach to collective rights and responsibilities is capable of accommodating a spectrum of broadly social democratic (including, perhaps, radical social liberal) or democratic socialist thinking, within which the individual may be framed as a citizen, but fundamentally as a member of human society. By way of illustration, it would accommodate the following statement by one of the respondents in the study: '[Social rights] are based on the concept of human rights and life with dignity. ... An individual shouldn't need to rely on his[/her] family or beg for money if (s/)he is in need, but society should make funds available.'

- A social contract based on a doctrinal conception of rights and an individualistic orientation would espouse an essentially utilitarian ethos and a range of constitutional, legal or regulatory principles. We might label this neo-Rawlsian. Rawls is celebrated for 
imagining how members of a hypothetical society - if they were ignorant of the position they would hold in that society - might agree to conjoin individual liberty with social justice. ${ }^{44}$ Recent followers, such as Stuart White, make a strong argument for rights founded in principles of 'fair reciprocity'. ${ }^{45}$ This approach to individual rights and responsibilities is capable of accommodating a broad spectrum of liberal approaches to 'fairness' - from right-wing neoliberalism to centre-ground social liberalism - within which the individual may be framed as a citizen, but usually also as an active worker or consumer. By way of illustration, it would accommodate the following statement by one of the respondents in the study: 'We have made a social contract [and] if I have a right it is up to the state to uphold it. ... I also have a responsibility, because the right I have is the opportunity to participate in the community I'm in.'

- A social contract based on a claims-based conception of rights and a solidaristic orientation would espouse a civic-republican ethos and subsidiaristic/social insurance principles. We would label this Rousseauian. Rousseau's emphasis was on a social contract distilled from, and legitimised through, the common will. ${ }^{46}$ This approach is concerned with the maintenance of collective commitment and is capable of accommodating a spectrum of social Conservative and Christian Democratic thinking. It is consistent, for example, which the emphasis in Catholic moral teaching on solidarity and subsidiarity. By way of illustration, it would accommodate the following statement by one of the respondents in our study: 'Those who pay taxes and social insurance secure the social rights for those who, because of falling into difficulty ... rely on the solidarity of others. That is how the great risks in life ... are financed.'

- A social contract based on a claims-based conception of rights and an individualistic orientation would espouse an essentially sceptical ethos and subscribe to basic survival principles. We have labelled this Hobbesian. Hobbes infamously denigrated social existence as a war of all against all, necessitating a bargain whereby certain freedoms must be constrained in return for the protection of the individual against the predations of others. ${ }^{47}$ His conception of the individual and the role of authority drew inspiration from Luther ${ }^{48}$ and was wholly consistent with punitive Poor Law traditions. This approach is more concerned with individual responsibilities than rights, but accommodates the idea that people should be enabled to survive; that there should be a safety net, albeit that it may be subject to conditions or judgements as to the moral desert of the supplicant. By way of illustration, it is expressed through the minimalism reflected in the following statement by one of the respondents in the study: 'A social right ensures ... that you can survive ... that you are not dying on the street or dying of starvation.'

To explore these underlying discourses the interview transcripts were analysed in two sweeps: the first, using the taxonomic categorisations outlined above to identify the dominant and sub-dominant discourses employed in each transcript; the second to identify from the textual context whether participants were expressing (or 'voicing') broad support or criticism of their country's prevailing social rights regime. Respondents had not necessarily been selected on the basis that they were left- or right-wing politicians or commentators or that they were government or opposition supporters, so we based our classification of critical and

\footnotetext{
${ }^{44}$ Rawls, John (1972), A Theory of Justice, Oxford: Oxford University Press.

${ }^{45}$ White, Stuart (2003), The Civic Minimum, Oxford: Oxford University Press.

${ }^{46}$ Rousseau, Jean-Jacques (1997), 'Of the Social Contract or Principles of Political Right' in Victor Gourevitch, Rousseau: The Social Contract and Other Later Political Writings, Cambridge: Cambridge University Press.

${ }^{47}$ Hobbes, Thomas (1991), Leviathan, Cambridge: Cambridge University Press.

${ }^{48}$ Overhoff, Jürgen (1997), 'The Lutheranism of Thomas Hobbes', Political Thought 4 (18), 604-24.
} 
supportive forms of discourse on the content of the transcripts, not the status of the respondents. The outcome may be regarded as a snapshot of the pattern of discourses to be found among a disparate community of policy actors from across the EU. The balance between supportively and critically voiced discourses varied between countries, but overall there was twice as much supportively voiced framing as critically voiced framing. This, however, was of less relevance than the distribution of supportively and critically voiced framing within each category of discourse: the discourses appeared to provide the essential terrain upon which agreement and disagreement could occur. It could clearly be seen that there was no unanimity across Europe as to the understanding of social rights. What is more, variation of discourse and understanding within countries would appear to have been as significant as variations between countries.

- Neo-Rawlsian discourse was prevalent and, arguably, hegemonic. It was generally dominant, especially in the context of voices supportive of prevailing regimes.

- Rousseauian discourse had a strong presence, whether voiced in a supportive or critical context.

- Critical voices were especially evident within 'global' discourse.

- Hobbesian discourse was not that much in evidence. Unsolicited concerns were expressed by respondents with regard to alleged social rights 'tourism', but such concerns may have stemmed less from judgementalism towards migrants on the part of the respondents as from their sensitivity to controversy driven by popular opinion.

There were disjunctures between social rights oriented discourse and social policy oriented discourse. These two orientations are not necessarily coterminous. Social policy may be framed without regard to the consideration of social rights, and yet social rights may be realised nevertheless. Conceptions of social rights as rights of citizenship, if they existed in the minds of policy actors, could vary, they could be contradictory, or they could be confused. Certainly, the association between social rights and any idea of cosmopolitan, supra- or post-national citizenship was at best tenuous. The barriers to the defence and promotion of social citizenship in Europe lay not so much with prevailing inconsistencies in the de facto realisation of social rights, as with conceptual uncertainty and ideological diversity.

\section{Barriers to the consensual construction of supranational social rights}

The evidence discussed above suggests that the original commitment to social rights and the welfare state across Europe became sustainable by virtue of a consensus initially stimulated by a social liberal impetus. This was an impetus that may have stemmed at different moments and in various ways: for example, from the legacy of Thomas Paine's radical liberalism; ${ }^{49}$ from the nineteenth century Krausist movement which facilitated accommodation between secular and religious thinking; and later, from emergent strands of mid-twentieth century liberalism, such as German 'ordoliberalism ${ }^{150}$ and in the Anglophone world the social liberalism of F.D. Roosevelt and Beveridge. Together these amounted to a form of liberalism, arguably, more tolerant of ideological pluralism than the currently prevailing economistic neoliberal orthodoxy; a liberalism to which the competing solidaristic principles of social conservatism and social democracy could in part at least accommodate themselves. We have seen, however, that the hegemonic conception of citizenship across Europe appears

\footnotetext{
${ }^{49}$ Paine, Thomas (1984), 'The Rights of Man', Harmondsworth: Penguin.

${ }^{50}$ A term first coined in the 1930s by the Freiburg School of economic thought, but more recently and more widely referred to as 'Social Market liberalism'.
} 
increasingly liberal/individualistic, rather than social liberal. In so far as the EU continues to appeal to solidarity, its appeals of late have been to solidarity between nations in the face of global economic and migration crises, not solidarity between citizens.

It is contended above that the bearer of social rights within the modern welfare state was first constituted as a worker. ${ }^{51}$ During the Western European era first heralded by the Westphalian Treaty ${ }^{52}$ and later consummated by the rise of industrial capitalism, the legal status and self-identity of nation sates and wage labourers were forged in conjunction with one another. Solidarity between citizens was premised on a coincidence of national and worker identity that does not necessarily apply in the post-Westphalian, post-industrial capitalist era. The dominant principle on which the earliest welfare states were founded was the social insurance principle; upon nationally organised risk sharing between individual workers. The application of the principle was initially pioneered in Germany by Bismark (who - it should be noted - was both a Conservative and a Protestant), where it was embraced by the opposing forces of Catholicism, on the one hand, and Social Democrats, on the other. The essential principle was adopted across Europe and beyond. But the social liberal impetus and the social insurance principle have together been undermined as the status and identity of both nation states and individual workers were eroded, by globalisation; ${ }^{53}$ by the changing nature of work under capitalism; $;{ }^{54}$ and by secular shifts in the nature and cultural understanding of individual risk. ${ }^{55}$

The bearer of social rights may now be constituted as much as the consumer of social services as a worker or, if she is not wholly self-sufficient, as much as a supplicant in need of conditional social support as a citizen. The basis for solidarity between citizens based on the social insurance principle has not been eclipsed, but it has been weakened, even within the classic Bismarkian states of continental Europe (Palier 2012) ${ }^{56}$ We have seen that, to varying extents, wider solidaristic convictions survive within policymaking discourse ${ }^{57}$ though they may be overshadowed by neo-liberal assumptions. Arguably, a more solidaristic form of European social citizenship must axiomatically embrace a supranational perspective; it must recognise that citizenship need not be primarily constituted through labour market participation; it must seek a risk-sharing principle that, as the social insurance principle once did, can be accommodated to competing ideological perspectives, or to competing discursive constructions of a social contract. Let us consider the implications of each of the ideal types of discursive construction identified above and the prospects of their accommodation to some form of consensus.

\section{1.'Global' social contact discourse: a hopeless cause?}

\footnotetext{
${ }^{51}$ Offe, Claus (1984), Contradictions of the Welfare State, Cambridge, Mass: MIT Press.

52 The treaty that ended the Thirty Years War in 1648, but which also established the basis of social order in Europe, premised on the 'modern' concept of national sovereignty.

${ }^{53}$ Held, David and Anthony McGrew (2007), Globalization/Anti-Globalization, Cambridge: Polity.

${ }^{54}$ Sennett, Richard (1998), The Corrosion of Character: The Personal Consequences of Work in the New Capitalism, New York: Norton; Doogan, Kevin (2009), New Capitalism? The Transformation of Work, Cambridge: Polity.

${ }^{55}$ Beck, Ulrich (1992), Risk Society: Towards a New Modernity, London: Sage; Beck, Ulrich and Elisabeth Beck-Gernsheim (2001), Individualization, London: Sage Publications.

${ }^{56}$ Palier, Bruno (2010), 'Continental Western Europe', in Francis Castles, The Oxford Handbook of the Welfare State, Oxford: Oxford University Press.

${ }^{57}$ That is to say in all but one of the European countries studied. The exception was Estonia, but since it had been possible to secure interviews with only three key informant interviews in this country, no conclusion on the point should be drawn.
} 
What was characterised above as the 'global' social contract discourse encompasses the social citizenship ideal that is in principle most evidently capable of embracing a supranational perspective, but as we have seen it appears to be far from dominant among European policy actors. The leap from social rights premised upon national citizenship to social rights premised on a global/human rights perspective remains elusive so long as the supposed universality of certain social rights is constrained by residency requirements based on national boundaries (see Chapter 4, this volume). The possibility of a world that could accommodate migration without borders, though debated, ${ }^{58}$ has - in terms of its relevance for social rights - been at best only partially achieved within the limited compass of the EU.

Applied to the ideal of social Europe, the universalistic logic underpinning the 'global' social contract discourse implies that that social rights should become effectively panEuropean. Such a goal has found one form of expression in calls for a Universal Basic Income such as that proposed as recently as 2013 by a European Citizens' Initiative, which sought, in the long term:

to offer to each person in the EU the unconditional right as an individual, to having his/her material needs met to ensure a life of dignity as stated by the EU treaties, and to empower participation in society supported by the introduction of the UBI. [http://ec.europa.eu/citizens-initiative/public/initiatives/obsolete/details/2013/000001 accessed 10 August 2016]

The initiative attracted only 285,000 signatures or 'statements of support' from EU citizens, and so failed by some margin to pass the overall 1 million signature threshold required to secure its formal consideration. The concept of a universal basic income, or a Citizen's Income, has been widely discussed. It is the subject of ongoing international debate under the auspices of BIEN (the Basic Income Earth Network - see www.basicincome.org). Limited forms of basic income have been introduced in places as diverse as Alaska and Iran. Smallscale experiments have been conducted in Canada, Namibia and India and are planned within Europe in the Netherlands (in Utrecht) and Finland. Albeit for different reasons, various versions of the basic income concept find favour among commentators from the radical left, ${ }^{59}$ the radical right ${ }^{60}$ and among a spectrum of social policy experts, ${ }^{61}$ but they struggle to find wider support. A basic income proposal presented in a referendum in Switzerland in 2016 was decisively rejected by the electorate. For the present it represents, perhaps, more of a totemic ideal than a practical proposition.

We may reflect more generally that the evolution and the purchase of a 'global' social contract ideal within social policy is constrained by barriers raised through trends that have

\footnotetext{
${ }^{58}$ Pécoud, Antoine and Paul de Guchteneire (2005), Migration without Borders: An Investigation into the Free Movement of People, Paris: UNESCO Global Commission on International Migration; Entzinger, Han (2007), 'Open Borders and the Welfare State' in Antoine Pecoud and Paul de Guchteniere, Migration without Borders: Essays on the Free Movement of People, Paris: UNESCO/Berghahn Books.

${ }^{59}$ Callinicos, Alex (2003), An Anti-Capitalist Manifesto, Cambridge: Polity.

${ }^{60}$ Murray, Charles (2008), The Social Contract Revisited: Guaranteed Income as a Replacement for the Welfare State, Oxford: The Foundation for Law Justice and Society/The Centre for Socio-Legal Studies.

${ }^{61}$ Van Parijs, Philippe (1992), Arguing for Basic Income, London: Verso. See also report of interview with Van Parijs, "An unconditional basic income in Europe will help end the crisis", given 11 April 2014 following a conference on the "Unconditional Basic Income" organised in the European Economic and Social Committee and reported at www.euractiv.com/sections/social-europe-jobs/van-parijs-unconditional-basic-income-europewill-help-end-crisis-301503 [accessed 4/9/15]); also Torry, Malcolm (2013), Money for Everyone: Why We Need a Citizen's Income, Bristol: The Policy Press; and Torry, Malcolm (2016), The Feasibility of Citizen's Income, Basingstoke: Palgrave Macmillan; Standing, Guy (2009), Work after Globalization: Building Occupational Citizenship, Cheltenham: Edward Elgar; Standing, Guy (2014), A Precariat Charter: From Denizens to Citizens, London: Bloomsbury.
} 
bolstered the three other competing social contract discourses, making an accommodation between discourses more difficult. The quest for a common understanding of social citizenship rights faces what might be described as a trilemma: a confluence of three movements, each with conflicting priorities - first, demands for welfare austerity and restricted social rights; second, the trend to the individualisation of social risk and greater selectivity of social rights; and third, the emergence of welfare state chauvinism, portending potentially an end to the social European ideal. We shall consider each in turn.

\subsection{Neo-Rawlsian social contract discourse and the 'austerian' turn}

What was characterised above as the neo-Rawlsian social contract discourse encompasses a social citizenship ideal in which rights and duties of the individual and the community are 'fairly' balanced, albeit that the balancing process may be perceived in terms of an increasingly austere reciprocal calculus. There is nothing new about demands for austerity in times of economic difficulty, ${ }^{62}$ nor the 'alchemic' synthesis of economic and moral imperatives implied by such demands. ${ }^{63}$ What characterises the emergence of twenty-first century demands for welfare state retrenchment and permanent austerity ${ }^{64}$ is not so much the economic logic of neoliberal argument as the cultural hegemony of what has been characterised as an 'austerian ideology', ${ }^{65}$ which came to a head with the global financial and fiscal crises precipitated in 2008.

A social liberal compromise with austerian neo-liberalism had been sought - in various guises by Clinton in the USA, Blair in the UK and Schröder in the Germany - in the 1990s and early 2000s through the 'Third Way' project. ${ }^{66}$ A key component of that compromise was the idea of 'social investment': a reframing of social expenditure as productive investment in human capital, rather than supposedly wasteful spending. ${ }^{67}$ The paradigm of social investment has lately undergone something of a revival. ${ }^{68}$ It advocates neither a return to Keynesian expansionism nor a continuation of neoliberal supply-side oriented welfare retrenchment, but an emphasis on productive potential of policies to enhance early childhood development, higher education and skills training, work-family reconciliation, and active ageing. Such policies can most certainly win some favour among both social democrats and economic liberals, but the underlying logic is essentially instrumentalist. Social rights are constituted as a means to an economic end, rather than as an inherent component of citizenship: the fairness of the social contract is evaluated with primary reference to the productive potential of the citizen.

\subsection{Rousseauian social contract discourse and the individualisation of risk}

\footnotetext{
${ }^{62}$ Blyth, Mark (2013), Austerity: The History of a Dangerous Idea, Oxford: Oxford University Press; Jessop, Bob (2015), 'Neolibrealism, Finance-Dominated Accumulation and Enduring Austerity: A Cultural Political Economy Perspective', in Kevin Farnsworth and Zoë Irving, Social Policy in Times of Austerity: Global Economic Crisis and the New Politics of Welfare, Bristol: The Policy Press.

${ }^{63}$ Clarke, John and Janet Newman (2012), 'The Alchemy of Austerity', Critical Social Policy 3 (32), 299-319.

${ }^{64}$ Pierson, Paul (2001), 'Coping with Permanent Austerity', in P. Pierson, The New Politics of the Welfare State, Oxford: Oxford University Press.

${ }^{65}$ Krugman, Paul (2015), 'The Austerity Delusion', The Guardian (29 April 2015).

${ }^{66}$ Giddens, Tony (1998), The Third Way, Cambridge: Polity.

${ }^{67}$ Lister, Ruth (2004), 'The Third Way's Social Investment State' in J. Lewis and R. Surender, Welfare State Change: Towards a Third Way?, Oxford: Oxford University Press.

${ }^{68}$ Hemerijck, Anton (2013), Changing Welfare States, Oxford: Oxford University Press; Morel, Nathalie, Bruno Palier and Joakim Palme (eds.) (2012), Towards a Social Investment State? Ideas, Policies and Challenges, Bristol: The Policy Press.
} 
What was characterised above as the Rousseauian social contract discourse encompasses a social citizenship ideal in which rights derive from the sharing of risk. In so far as this was an ideal largely associated with Western continental Europe, it has been weakened as classically corporatist welfare states have, on the one hand, incrementally diluted the redistributive principles informing collective social insurance systems in favour of stricter actuarial principles and, on the other, responded to the changing nature of social risks through the introduction of flat-rate, tax-financed, non-contributory benefits to provide a social minimum for vulnerable social groups and targeted benefits for those excluded from the labour market. ${ }^{69}$ These changes may be associated in part with global cultural shifts favouring greater individualism ${ }^{70}$ and in part with the consequences of new social risks arising from socio-demographic trends affecting all developed economies. ${ }^{71}$

Nevertheless, social insurance arrangements had in some instances, as in the case of the classic Nordic model, been made deliberately 'encompassing' or inclusive. ${ }^{72}$ Declining schemes - such as that in the UK - could be revitalised and modified to provide more extensive coverage so as to meet the needs of citizens with restricted labour market access. ${ }^{73}$ Alternatively, it has been suggested, social insurance schemes could be not replaced, but supplemented by a form of Participation Income - a form of basic income that recognises social as well as economic contributions on the part of the citizen. ${ }^{74}$ The global trend, however, is not in this direction. The popularity of contributory social insurance appears to be in decline and the strength of neoliberal economic opinion that prefers conditional social assistance. It is symbolically significant that even the ILO - as a long-term international defender of the social insurance principle - has recently brokered an agreement between the developing countries of the world that promotes, not Social Security for All (as in the past), but a Social Protection Floor ${ }^{75}$ : a vision that incorporates a role for targeted social assistance rights.

\subsection{Hobbesian social contract discourse and populist resistance to cosmopolitanism}

What was characterised above as the Hobbesian social contract discourse encompasses a restrictive social citizenship ideal that seeks to defend the interests of the individual against unwarranted claims by others. From the perspective of the policymaker it is an ideal that might favour minimal social entitlements and/or entitlements based on moral desert. But from the perspective of the ordinary citizen it is an ideal that demands the defence of such entitlements as they have against erosion by others: by underserving members of their own society and/or by outsiders. As we have seen, the Hobbesian discourse among the European policy actors interviewed for the study described above was not much in evidence, except as a reflection of, or as a response to, popular anxieties.

Popular anxieties of this nature, expressed through right-wing populist movements, appear to have been rising since the 1990s, when they were first attributed to a form of

\footnotetext{
${ }^{69}$ Palier, Bruno (2010), 'Continental Western Europe', in F. Castles, The Oxford Handbook of the Welfare State, Oxford: Oxford University Press.

${ }^{70}$ Inglehart, Ronald (1990), Culture Shift in Advanced Industrial Society, Princeton NJ: Princeton University Press.

${ }^{71}$ Taylor-Gooby, Peter (2000), Risk, Trust and Welfare, Basingstoke: Macmillan.

${ }^{72}$ Kautto, Miko (2010), 'The Nordic Countries' in Francis Castles, The Oxford Handbook of the Welfare State, Oxford: Oxford University Press.

${ }^{73}$ Bell, Kate and Declan Gaffney (2012), Making a Contribution: Social Security for the Future, London: Trades Union Council.

74 Atkinson, Tony (1996), 'The Case for a Participation Income', Political Quarterly 1 (67), 67-70.

${ }^{75}$ Deacon, Bob (2012), 'The Social Protection Floor', CROP Poverty Brief no. 11.
} 
'welfare state chauvinism'. ${ }^{76}$ It has been suggested that social and ethnic diversity may be fundamentally inimical to the solidarity required politically to support extensive social rights provision. ${ }^{77}$ Such claims are refuted by evidence that strong welfare states can promote tolerance of diversity. ${ }^{78}$ Nevertheless, there is evidence of support for welfare state chauvinism - as both a socio-economic and a socio-cultural phenomenon - across Europe. ${ }^{79}$ Such support may be fuelled by 'austerian' ideology and the idea that access to finite resources must be rationed, but it is also underpinned by a moral-authoritarian rejection of the idea that others - of a different culture, ethnicity or nationality - should enjoy the same rights as supposedly indigenous citizens. It is widely contended that populist sentiment of this nature played some part at least in the outcome in 2016 of the UK referendum on EU membership and has led to 'Brexit'. ${ }^{80}$

But, of course, recent events across Europe have also given birth to very different anti-establishment popular movements, fuelled primarily by resistance to neoliberal austerity, yet implicitly informed by awareness of social rights as a collective good, rather than a residual burden. ${ }^{81}$ The Occupy movement that had a presence in several Northern European cities $^{82}$ and new parties mobilising significant popular support - Podemos in Spain, the Five Star Movement in Italy, Syriza in Greece - suggest in disparate ways that it is sometimes possible for bottom-up social movements to demand inclusive social rights. Nevertheless, the strength of Hobbesian populism's opposition to a cosmopolitan European ideal appears to impose a significant constraint on the realisation of a genuinely transnational form of European social citizenship.

\subsection{Social contract discourse and the migrant}

While the focus within much of this volume is upon the social rights of intra-EU migrants, the deliberate focus of this chapter, and the research on which it is founded, has been upon EU citizens in general. Nevertheless, our discussion of social contract discourse provides a context that has implications for the manner in which the migrant, including the intra-EU migrant citizen, might be socially constructed. ${ }^{83}$ The social contract alluded to by respondents in our study of European policy actors was primarily a national social contract, to which the migrant - whether she be a third country national of a citizen of another EU country - would be a stranger. Certainly, within the Hobbesian social contact discourse, the intra-EU migrant might characteristically be constructed as an alien intruder and a total stranger to the national social contact. Within the Rousseauian social contact discourse, the intra-EU migrant might characteristically be constructed as a guest and, at best, a temporary or partial party to the national social contact. Within the Rawlsian social contact discourse, the intra-EU migrant might characteristically be constructed as potential settler and, perhaps, a conditional party to

\footnotetext{
${ }^{76}$ Andersen, Jørgen G. (1992), 'Denmark: The Progress Party - Populist Neoliberalism and the Welfare State' in P. Hainsworth, The Extreme Right in Europe and the USA, London: Pinter.

${ }^{77}$ Alesina, Alberto and E. Glaeser (2004), Fighting Poverty in the US and Europe, Oxford: Oxford University Press.

${ }^{78}$ Banting, Keith and Will Kymlicka (2006), Multiculturalism and the Welfare State, Oxford: Oxford University Press; Crepaz, Markus and Regan Damron (2009), 'Constructing Tolerance: How the Welfare State Shapes Attitudes About Immigrants', Comparative Political Studies 3 (42), 437-63.

${ }^{79}$ Mewes, Jan and S. Mau (2012), 'Unravelling Working Class Welfare Chauvinism' in S. Svallfors, Contested Welfare States: Welfare Attitudes in Europe and Beyond, Stanford, CA: Stanford University Press.

${ }^{80}$ MacShane, Denis (2015), Brexit: How Britain Will Leave the EU, London: Tauris.

${ }^{81}$ Piven, Frances F. and L. Minnite (2015), 'Crisis, Convulsion and the Welfare State' in K. Farnsworth and Z. Irving, Social Policy in Times of Austerity, Bristol: The Policy Press.

${ }^{82}$ Pickerill, Jenny and J. Krinsky (2012), 'Why Does Occupy Matter?', Social Movement Studies: Journal of Social, Cultural and Political Protest 3-4 (11), 279-187.

${ }^{83}$ Dean, Hartley (2011), 'The Ethics of Migrant Welfare', Ethics and Social Welfare 1 (5), 18-35.
} 
the national social contact. The exception here would be the global social contract discourse. This discourse could apply 'globally', as we have seen, either to a notional contract between the individual and humanity, or metaphorically to a universal contract between every resident and the state within which she resides. By either interpretation, the migrant might be acknowledged not as a stranger, but as a newly arrived party to a social contract realised at a national level. It should be noted, however, that the idea of a social contact between the EU citizen and the EU as a supranational entity was never explicitly raised and appeared to be quite absent from the discourses drawn upon by the policy actors in our study. When considered specifically in relation to the social rights of migrants, EU citizenship is an idea that does not seem to have taken hold, or else has been obscured or residualised by national preoccupations.

\section{Conclusion}

Barriers to a consensus of meaning across Europe that might match that which informed the development of social rights in the classic national welfare states within Europe may be insuperable. It is unlikely that the ideal of a shared European citizenship is one that can extend to a shared form of social citizenship in the Marshallian sense. But diverse forms of social citizenship will continue to develop. The challenge for the EU, if it is to survive, is better to comprehend the clumsy contradictions and the constructive commonalities of understanding both between and within its Member States. The question for the EU is how best to nurture a critically supportive framework to optimise the effectiveness and sustainability of the complex array of social rights that already exist or that may emerge in different countries across Europe.

\section{References}

Alesina, Alberto, and Edward Glaeser. Fighting Poverty in the Us and Europe. Oxford: Oxford University Press, 2004.

Andersen, Jørgen Goul. "Denmark: The Progress Party - Populist Neoliberalism and the Welfare State." In The Extreme Right in Europe and the USA, edited by Paul Hainsworth. London: Pinter, 1992.

Atkinson, Anthony. "The Case for a Participation Income." Political Quarterly 67, no. 1 (1996): 67-70.

Bailey, David. "Explaining the Underdevelopment of 'Social Europe': A Critical Realisation." Journal of European Social Policy 18, no. 3 (2008): 232-45.

Banting, Keith, and Will Kymlicka. Multiculturalism and the Welfare State. Oxford: Oxford University Press, 2006.

Barbier, Jean-Claude. "To What Extent Can the European Union Deliver 'Social Citizenship' to Its Citizens?". In Social Policy and Citizenship: The Changing Landscape, edited by Adelbert Evers and Anne-Marie Guillemard. Oxford: Oxford University Press, 2013.

Beck, Ulrich. Risk Society: Towards a New Modernity. London: Sage, 1992.

Beck, Ulrich, and Elisabeth Beck-Gernsheim. Individualization. London: Sage Publications, 2001.

Bell, Kate, and Declan Gaffney. Making a Contribution: Social Security for the Future. London: Trades Union Council, 2012. 
Beveridge, William. Social Insurance and Allied Services. Cmd. 6404 ed. London: HMSO, 1942.

Blyth, Mark. Austerity: The History of a Dangerous Idea. Oxford: Oxford University Press, 2013.

Bonoli, Giuliano. "Classifying Welfare States." Journal of European Social Policy 26, no. 2 (1997): 352-72.

Brodkin, Evelyn, and Gregory Marston, eds. Work and the Welfare State. Copenhagen: DJØF Publishing, 2013.

Callinicos, Alex. An Anti-Capitalist Manifesto. Cambridge: Polity, 2003.

Cerami, Alfio, and Pieter Vanhuysse. Post-Communist Welfare Pathways: Theorizing Social Policy Transformations in Central and Eastern Europe. Basingstoke: Palgrave, 2009.

Clarke, John, and Janet Newman. "The Alchemy of Austerity." Critical Social Policy 32, no. 3 (2012): 299-319.

Commission for the European Communities (CEC). European Social Policy: Options for the Union. Luxembourg: OOPEC, 1993.

Crepaz, Markus, and Regan Damron. "Constructing Tolerance: How the Welfare State Shapes Attitudes About Immigrants." Comparative Political Studies 42, no. 3 (2009): 437-63.

Davy, Ulrike. "Social Citizenship Going International: Changes in the Reading of UnSponsored Economic and Social Rights." International Journal of Social Welfare 22, no. Supplement 1 (2013): S15-S31.

Deacon, Bob. "The Social Protection Floor." CROP Poverty Brief, no.11. October (2012).

Dean, Hartley. "The Ethics of Migrant Welfare." Ethics and Social Welfare 5, no. 1 (2011): 18-35.

- Social Rights and Human Welfare. Abingdon: Routledge, 2015.

. Social Security and Social Control. London: Routledge, 1991.

. "The Translation of Needs into Rights: Reconceptualising Social Citizenship as a Global Phenomenon." International Journal of Social Welfare 22, no. Supplement 1 (2013): S32-S49.

Dean, Hartley, and Anne-Marie Brady. The Social Construction of Social Rights across Europe (D6.3 Report). Utrecht: bEUcitizen (Barriers towards EU citizenship) EU Seventh Framework Programme IP, 2015.

Dean, Hartley, with Margaret Melrose. Poverty, Riches and Social Citizenship. Basingstoke: Macmillan (1999).

Delors, Jacques. "L'espace Social Européén." 2 EC 12 (1986).

Donnelly, Jack. Universal Human Rights in Theory and Practice. 3rd ed. Ithaca: NY: Cornell University Press, 2013.

Doogan, Kevin. New Capitalism? The Transformation of Work. Cambridge: Polity, 2009.

Entzinger, Han. "Open Borders and the Welfare State." In Migration without Borders: Essays on the Free Movement of People, edited by Antoine Pecoud and Paul de Guchteniere. Paris: UNESCO/Berghahn Books, 2007.

Esping-Andersen, Gøsta. The Social Foundations of Post-Industrial Economies. Oxford: Oxford University Press, 1999.

. The Three Worlds of Welfare Capitalism. Cambridge: Polity, 1990.

Falkner, Gerda. "The Treaty on European Union and Its Revision: Sea Change or Empty Shell for European Social Policies?". In Survival of the European Welfare State, edited by Stein Kuhnle. London: Routledge, 2000.

Ferragina, Emanuelle, and Martin Seeleib-Kaiser. "Thematic Review: Welfare Regime Debate - Past, Present, Futures?". Policy and Politics 39, no. 4 (2011): 583-611. 
Ferrera, Maurizio. The Boundaries of Welfare: European Integration and the New Social Politics of Social Protection. Oxford: Oxford University Press, 2005.

Foucault, Michel. (1965). Madness and Civilisation: A history of insanity in the Age of Reason. London: Tavistock, 1965.

Freeman, Michael. Human Rights. 2nd ed. Cambridge: Polity, 2011.

George, Vic, and Paul Wilding. Ideology and Social Welfare. London: Routledge and Kegan Paul, 1985.

Giddens, Anthony. The Third Way. Cambridge: Polity, 1998.

Hantrais, Linda. Social Policy in the European Union. 3rd ed. Basingstoke: Macmillan, 2007.

Held, David, and Anthony McGrew. Globalization/Anti-Globalization. 2nd ed. Cambridge: Polity, 2007.

Hemerijck, Anton. Changing Welfare States. Oxford: Oxford University Press, 2013.

Hermann, Christoph. "Neoliberalism in the EU." Studies in Political Economy 79 (2007): 6189.

Hobbes, Thomas. Leviathan. Ed. Richard Tuck - 1991 revised student ed. Cambridge: Cambridge University Press, 1651.

Honneth, Axel. The Struggle for Recognition: The Moral Grammar of Social Conflicts. Cambridge: Polity, 1995.

Inglehart, Ronald. Culture Shift in Advanced Industrial Society. Princeton NJ: Princeton University Press, 1990.

Isin, Engin, Janine Brodie, Danielle Juteau, and Daiva Stasiulis. "Recasting the Social in Citizenship." In Recasting the Social in Citizenship, edited by Engin Isin. Toronto: University of Toronto Press, 2008.

Janoski, Thomas. Citizenship and Civil Society: A Framework of Rights and Obligations in Liberal, Traditional and Social Democratic Regimes. Cambridge: Cambridge University Press, 1998.

Jessop, Bob. The Future of the Capitalist State. Cambridge: Polity, 2002.

. "Neolibrealism, Finance-Dominated Accumulation and Enduring Austerity: A Cultural Political Economy Perspective." In Social Policy in Times of Austerity: Global Economic Crisis and the New Politics of Welfare, edited by Kevin Farnsworth and Zoë Irving. Bristol: The Policy Press, 2015.

Kautto, Miko. "The Nordic Countries." In The Oxford Handbook of the Welfare State, edited by Francis Castles, Stephan Leibfried, Jane Lewis, Herbert Obinger and Christopher Pierson. Oxford: Oxford University Press, 2010.

Krugman, Paul. "The Austerity Delusion." The Guardian (29 April) (2015).

Leibried, Stephan. "National Welfare States, European Integration and Globalization: A Perspective for the Next Century." Social Policy and Administration 34, no. 1 (2000): 44-63.

Lister, Ruth. Citizenship: Feminist Perspectives, Second Edition. Basingstoke: Macmillan, 2003.

"The Third Way's Social Investment State." In Welfare State Change: Towards a Third Way?, edited by Jane Lewis and Rebecca Surender. Oxford: Oxford University Press, 2004.

MacShane, Denis. Brexit: How Britain Will Leave the EU. London: Tauris, 2015.

Marshall, Thomas, H. "Citizenship and Social Class." In Citizenship and Social Class, edited by Thomas Marshall and Tom Bottomore. London: Pluto, 1950.

Mewes, Jan, and Steffen Mau. "Unravelling Working Class Welfare Chauvinism." In Contested Welfare States: Welfare Attitudes in Europe and Beyond, edited by Stefan Svallfors. Stanford, CA: Stanford University Press, 2012. 
Morel, Nathalie, Bruno Palier, and Joakim Palme, eds. Towards a Social Investment State?: Ideas, Policies and Challenges. Bristol: The Policy Press, 2012.

Murray, Charles. The Social Contract Revisited: Guaranteed Income as a Replacement for the Welfare State. Oxford: The Foundation for Law Justice and Society/The Centre for Socio-Legal Studies, 2008.

Newman, Janet, ed. Remaking Governance: Peoples, Politics and the Public Sphere. Bristol: The Policy Press, 2005.

Offe, Claus. Contradictions of the Welfare State. Cambridge, Mass: MIT Press, 1984.

Overhoff, Jürgen. "The Lutheranism of Thomas Hobbes." Political Thought 18, no. 4 (1997): 604-24.

Paine, Thomas. The Rights of Man. 1984 edition ed. Harmondsworth: Penguin, 1791.

Palier, Bruno. "Continental Western Europe." In The Oxford Handbook of the Welfare State, edited by Francis Castles, Stephan Leibfried, Jane Lewis, Herbert Obinger and Christopher Pierson. Oxford: Oxford University Press, 2010.

Palier, Bruno, and Claude Martin, eds. Reforming the Bismarckian Welfare Systems. Oxford: Blackwell, 2008.

Pécoud, Antoine, and Paul de Guchteneire. Migration without Borders: An Investigation into the Free Movement of People (Global Migration Perspectives - Research Paper No. 27). Paris: UNESCO Global Commission on International MIgration, 2005.

Pickerill, Jenny, and John Krinsky. "Why Does Occupy Matter?". Social Movement Studies: Journal of Social, Cultural and Political Protest 11, no. 3-4 (2012): 279-187.

Pierson, Paul. "Coping with Permanent Austerity." In The New Politics of the Welfare State, edited by Paul Pierson. Oxford: Oxford University Press, 2001.

Piven, Frances Fox, and Lorraine Minnite. "Crisis, Convulsion and the Welfare State." In Social Policy in Times of Austerity, edited by Kevin Farnsworth and Zoë Irving. Bristol: The Policy Press, 2015.

Powell, Martin, and Martin Hewitt. Welfare State and Welfare Change. Buckingham: Open University Press, 2002.

Rawls, John. A Theory of Justice. Oxford: Oxford University Press, 1972.

Roosevelt, Franklin D. State of the Union Address to Congress 6 January. http://www.ourdocuments.gov/doc.php?flash=false\&doc=70\&page=transcript, 1941.

Rousseau, Jean-Jacques. "Of the Social Contract or Principles of Political Right." In Rousseau: The Social Contract and Other Later Political Writings, edited by Victor Gourevitch. 1997 ed. Cambridge: Cambridge University Press, 1762.

Scharpf, Fritz. "The European Social Model: Coping with the Challenges of Diversity." Journal of Common Market Studies 40, no. 4 (2002): 645-70.

Schmitter, Philippe, and Michael Bauer. "A (Modest) Proposal for Expanding Social Citizenship in the European Union." Journal of European Social Policy 11, no. 1 (2001): 55-65.

Sennett, Richard. The Corrosion of Character: The Personal Consequences of Work in the New Capitalism. New York: Norton, 1998.

Standing, Guy. A Precariat Charter: From Denizens to Citizens. London: Bloomsbury, 2014. - Work after Globalization: Building Occupational Citizenship. Cheltenham: Edward Elgar, 2009.

Sum, Ngai-Ling, and Bob Jessop. Towards Cultural Political Economy: Putting Culture in Its Place in Political Economy. Cheltenham: Edward Elgar, 2013.

Taylor-Gooby, Peter, ed. Risk, Trust and Welfare. Basingstoke: Macmillan, 2000.

Titmuss, Richard. The Gift Relationship. London: Allen and Unwin, 1970.

Torry, Malcolm. The Feasibility of Citizen's Income. Basingstoke: Palgrave Macmillan, 2016. 
—. Money for Everyone: Why We Need a Citizen's Income. Bristol: The Policy Press, 2013.

Turner, Bryan. Citizenship and Capitalism: The Debate over Reformism. London: Allen and Unwin, 1986.

van Parijs, Philippe, ed. Arguing for Basic Income. London: Verso, 1992.

Verweij, Marco, and Michael Thompson, eds. Clumsy Solutions for a Complex World:

Governance, Politics and Plural Perceptions. Basingstoke: Palgrave Macmillan, 2006.

Vielle, Pascal. "How the Horizontal Social Clause Can Be Made to Work: The Lessons of Gender Mainstreaming." ETUI Policy Brief - European Social Policy 2010, no. 6 (2010).

White, Stuart. The Civic Minimum. Oxford: Oxford University Press, 2003. 